\title{
Phage tf-1: A Filamentous Bacteriophage Specific for Bacteria Harbouring the IncT Plasmid pIN25
}

\author{
By J. N. COETZEE, ${ }^{1 *}$ D. E. BRADLEY, ${ }^{2}$ R. W. HEDGES, ${ }^{3}$ \\ MONICA TWEEHUIZEN ${ }^{1}$ AND LAUREEN DU TOIT ${ }^{1}$ \\ ${ }^{1}$ Department of Microbiology, University of Pretoria, and Bacterial Genetics Research Unit of the \\ South African Medical Research Council, PO Box 2034, Pretoria 0001, South Africa \\ ${ }^{2}$ Faculty of Medicine, Memorial University of Newfoundland, St. John's, Newfoundland, \\ Canada AlB 3 V6 \\ ${ }^{3}$ Plant Genetic Systems, Rijksuniversiteit Gent, Jozef Plateau Straat 22, B-9000, Gent, \\ Belgium
}

(Received 10 September 1986)

Phage $\mathrm{tf}-1$ is a filamentous phage which is about $800 \mathrm{~nm}$ in length, $10 \mathrm{~nm}$ in width and has slightly tapered ends. The phage was isolated from sewage and formed plaques or propagated only on Escherichia coli, Salmonella typhimurium and Klebsiella oxytoca strains harbouring the IncT plasmid pIN 25 at $30^{\circ} \mathrm{C}$. It adsorbed in large numbers to pIN25-encoded long thick flexible conjugative pili formed at $30^{\circ} \mathrm{C}$ and also to the short form of these pili synthesized at $37^{\circ} \mathrm{C}$. The reason for the failure to form plaques at $37^{\circ} \mathrm{C}$ is not known. The adsorption site is a short length of the pilus shaft extending 100-200 nm back from the distal tip. Efficient phage tf- 1 adsorption to the same site was found for pili determined by other IncT plasmids in spite of the fact that phage $t f-1$ did not plate or propagate on strains harbouring them. However, areas of specific partial clearing on lawns of these plasmid-containing bacteria were produced by phage in high concentrations. Lack of plaque-formation could be due to inefficient intracellular assembly coupled to avid adsorption of any liberated phage to pili. The phage differs from all but one other filamentous phage by being sensitive to diethyl ether.

\section{INTRODUCTION}

The IncT group of plasmids consists of Rts1 (the prototype), pIN25, R394, R401, R402 and R414b (see Bradley et al., $1981 b$ and Bradley \& Whelan, 1985). They were detected in species of the tribe Proteae. The first five plasmids are the best studied and, apart from R394, they possess replication mechanisms which are thermosensitive to various extents (Coetzee et al., 1972; Terawaki et al., 1967; Terawaki \& Round, 1972; Odakura et al., 1977; Bradley \& Whelan, 1985). The plasmids code for thick flexible pili at $30^{\circ} \mathrm{C}$ and, apart from Rts 1 , form pili constitutively (Bradley \& Whelan, 1985, but see Bradley, 1980a). The pili, which are serologically similar as judged by immune electron-microscopy using polyclonal antisera (To et al., 1975; Bradley, $1980 a$; Bradley \& Whelan, 1985), are long at $30^{\circ} \mathrm{C}$ but short (about $200 \mathrm{~nm}$ ) at $37^{\circ} \mathrm{C}$. This change is associated with a shift from a universal conjugation system at the lower temperature to surface-obligatory mating at $37^{\circ} \mathrm{C}$ (Bradley et al., 1980; Bradley \& Whelan, 1985).

The RNA-containing phage $\mathrm{t}$ adsorbs to the distal sides of IncT pili (Bradley et al., $1981 \mathrm{~b}$ ). It lyses bacteria harbouring derepressed IncT plasmids at $30^{\circ} \mathrm{C}$ but not at $37^{\circ} \mathrm{C}$. This is thought to be due to the fact that although phage $t$ adsorbs to the short pili formed at the latter temperature (Bradley \& Whelan, 1985) the phage itself could have an undetermined temperature-sensitive step in the lytic cycle (Bradley \& Whelan, 1985). 
In order to possibly decide whether phage $t$ or the short pilus is responsible for the temperature effect it would be of interest to have a non-temperature-sensitive pilus-adsorbing phage to test whether short pili, apart from providing an adsorption site for the phage, are functional in further possible steps leading to productive infection (Beumer et al., 1984; Schwartz, 1980; Goldberg, 1980). To this end, unsuccessful attempts were made (unpublished results) to recover a mutant of phage $t$ capable of plating on plasmid-bearing strains at the higher temperature. Next, six more IncT-specific RNA-containing phages were isolated from sewage derived from widely dispersed localities in South Africa. All these phages had plaque-forming abilities similar to phage $t$ (unpublished results). We also isolated a filamentous phage active only on bacterial strains carrying the IncT plasmid pIN25. Here, properties of this phage, the first filamentous phage described adsorbing to IncT plasmid-coded pili, are presented.

\section{METHODS}

Bacteria. Escherichia coli strains used were JE2571 and the corresponding nalidixic-acid- and rifampicinresistant (rif ${ }^{\mathbb{R}}$ ) mutants JE2571-1 and -2 respectively (Bradley, 1980a, 1985) and strain CSH2 (Yokota et al., 1969). The Salmonella typhimurium strain was M827-2, a spontaneous rif ${ }^{\mathbb{2}}$ mutant of the LT2 strain M827 (Spratt et al., 1973). Sr41-2 is a spontaneous rif $^{\mathbb{R}}$ mutant (J. N. Coetzee, unpublished) of Serratia marcescens strain 41 (Matsumoto et al., 1973). Klebsiella pneumoniae G162 and K. oxytoca G147 were provided by Dr I. Simpson (Glaxo, Greenford, Middlesex, UK). The members of the tribe Proteae used were Proteus mirabilis PM5006 (Coetzee et al., 1979), P. morganii 2815-2 (Coetzee et al., 1985a), P. rettgeri NCTC 8893 (Coetzee, 1983) and R49 (Coetzee, 1972) and Providencia alcalifaciens P29-2 (Coetzee et al., 1985a).

Plasmids and bacteriophages. Plasmids were from the collection of N. Datta (Datta, 1979). The IncT plasmids (Bradley $e t$ al., 1981 b) are listed in Table 1. Other plasmids belonging to Inc groups C (Sirgel et al., 1981), D (Coetzee et al., 1985 b), $\mathrm{HI}$ and HII (Coetzee et al., 1985a), $\mathrm{I}_{1}$ and $\mathrm{I}_{2}$ (Coetzee et al., 1982), M (Coetzee et al., 1983), N, P and W (Coetzee et al., 1979) and S (Coetzee et al., 1986) were also used in phage host range experiments. Constitutive production of conjugative pili by the above plasmids was assessed by the ability of corresponding plasmid-specific phages, described in the same references, to form plaques on lawns of the plasmid-bearing organisms. Filamentous phages X (Bradley et al., 1981 a), IKe (Khatoon et al., 1972), C-2 (Bradley et al., 1982), PR64FS (Coetzee et al., 1980) and fd (Marvin \& Hoffmann-Berling, 1963) were compared serologically with phage tf-1 (see Results). The RNA-containing phage C-1 (Sirgel et al., 1981) and the filamentous phages mentioned above were used as controls in organic solvent and RNAase susceptibility tests.

Media and antibacterial agents. These were according to Coetzee et al. (1979).

Conjugal transfer of plasmids by plate mating. This was as described by Bradley et al. (1980).

General phage techniques and production of phage lysates. The methods of Adams (1980) were used.

Ribonuclease and organic solvent sensitivity of phage suspensions. These were determined as described by Bradley et al. (1981a) and Ackermann et al. (1978).

Temperature sensitivity of plaque formation. Because we wanted to avoid missing temperature-sensitive filamentous phages, isolation of phage from sewage (see below) was done at $30^{\circ} \mathrm{C}$ and $37^{\circ} \mathrm{C}$. The former incubation temperature was also used for work involving phages D (Coetzee et al., 1985b), pilH $\alpha$ (Coetzee et al., $1985 a$ ) and $t$ (Bradley et al., 1981 b). To obtain cultures of the temperature-sensitive (Bradley \& Whelan, 1985) IncT plasmid-bearing strains at $37^{\circ} \mathrm{C}$ or $42^{\circ} \mathrm{C}$, overnight cultures grown at $30^{\circ} \mathrm{C}$ were diluted 20 -fold in prewarmed broth containing the selective antibiotic of the particular plasmid at $30 \mu \mathrm{g} \mathrm{ml}^{-1}$ (Bradley \& Whelan, 1985). Cultures were then incubated at the desired temperature for $3.5 \mathrm{~h}$ before use (Ishaq \& Kaji, 1980). All plates were incubated overnight.

Filamentous phage isolation. This was done according to the method of Coetzee et al. (1985a) at the two temperatures mentioned above with the following modifications: batches of sewage $(20 \mathrm{ml})$, obtained from various sewage works in the Pretoria-Johannesburg area, were heated for $10 \mathrm{~min}$ at $90^{\circ} \mathrm{C}$ (Marvin \& Hohn, 1969) to eliminate many non-filamentous phages before being enriched with the IncT plasmid-bearing strains JE2572(R402), M827-2(R402), JE2571(R394), M827-2(R394), JE2571(R414b), M827-2(R414b), JE25712(pIN25) or M827-2(pIN25). After the incubation period the enriched sewage filtrates were spotted separately on soft agar lawns of all the above strains individually. The agar contained $25 \mu \mathrm{g}$ RNAase $\mathrm{ml}^{-1}$ (BDH) to eliminate RNA-containing phages (Watanabe \& August, 1967). The filtrates were also spotted on the isogenic strains lacking plasmids.

Phage antiserum. Rabbit antiserum against phage tf-1 (see Results) was prepared as described by Coetzee $e t$ al. (1985b) using strain JE2571-2 to adsorb somatic antibodies.

Phage growth on bacterial strains harbouring plasmids repressed for pilus synthesis. The methods of Coetzee et al. (1986) were used employing newly formed transconjugants of the particular plasmids under study. 
Electron microscopy. Techniques were generally as described by Bradley (1980a) and Bradley et al. (1981a). For the adsorption of phage tf-1 to pili, a small loopful of bacteria from a fresh overnight plate was suspended in $0.2 \mathrm{ml}$ of a high titre phage suspension in a $5 \mathrm{~cm}$ diameter Petri dish. After being mixed with a pipette, transferred to a second dish and covered tightly, the suspension was incubated for $2 \mathrm{~h}$ at $30^{\circ} \mathrm{C}$. A carbon-coated support grid was then touched on the surface, and negative staining done as described by Bradley $(1980 a)$ and Bradley et al. (1981 $a$ ). For Rtsl pili, bacteria were grown by the 'temporary derepression' method (Bradley, 1980).

\section{RESULTS}

\section{Isolation of phage t $f-1$}

From the one hundred and fourteenth specimen of sewage investigated, a phage was isolated on JE2571-2(pIN25) at $30^{\circ} \mathrm{C}$ which did not plate on the isogenic strain lacking the plasmid. Because of its filamentous morphology, limited host range and possible temperature sensitivity (see below) it was named phage tf- 1 . It was routinely propagated on the above strain at $30{ }^{\circ} \mathrm{C}$ and plaque-forming titres of at least $5 \times 10^{11} \mathrm{ml}^{-1}$ were regularly obtained.

\section{Properties of phage $t \mathrm{f}-1$}

Plaque morphology and temperature sensitivity of plaque formation. Triplicate experiments done entirely at 30,37 and $42{ }^{\circ} \mathrm{C}$ respectively revealed that the phage formed plaques only on strain JE2571-2(pIN25) at $30^{\circ} \mathrm{C}$. Plaques were turbid in appearance and varied in size from pin-point to about $1.5 \mathrm{~mm}$ in diameter. The larger plaques were often irregular in outline. Experiments with other phage-sensitive host strains (Table 1) gave similar results (not shown). Plating a total of $2 \times 10^{12}$ p.f.u. on a culture of JE2571-2(pIN25) at $37^{\circ} \mathrm{C}$ did not yield a plaque.

Morphology and adsorption site. Phage tf-1 was filamentous, about $800 \mathrm{~nm}$ long and slightly less than $10 \mathrm{~nm}$ thick. Both ends were slightly tapered and no exceptional structures, possibly indicative of lipid, were seen (see Coetzee et al., 1979, Figs 1-3). Double-length virions were common, but those adsorbed to pili were predominantly $800 \mathrm{~nm}$ in length (see below) and therefore represented the correctly assembled infective unit. With both pilus growth (overnight) and adsorption $(2 \mathrm{~h})$ at $30^{\circ} \mathrm{C}, \mathrm{tf}-1$ adsorbed to the shafts (sides) of $\mathrm{T}$ pili determined by pIN 25 (Fig. 1a), R402 (Fig. 1b), Rts1 (Fig. 1c), and R394 (not illustrated; pili of other IncT plasmids not tested). The adsorption site was restricted to a short length of pilus (100-200 nm) extending back from the pointed tip and in some cases it appeared confined to a ring where the tapering starts (Fig. 1b). The site corresponded more or less to the adsorption site of the RNA phage $t$ (Bradley et al., 1981 b). Adsorption was apparently very efficient as large numbers of virions were invariably attached within this region, usually aggregating into two or three dense bundles (Fig. 1c). Similar adsorption $\left(2 \mathrm{~h}\right.$ at $\left.30^{\circ} \mathrm{C}\right)$ was observed with the short form of $\mathrm{T}$ pilus synthesised at $37^{\circ} \mathrm{C}$ (Bradley \& Whelan, 1985), using pIN25 pili. Likewise phage tf-1 adsorbed to long pIN25 pili (grown at $30^{\circ} \mathrm{C}$ ) after incubation at $37^{\circ} \mathrm{C}$ for $2 \mathrm{~h}$ (not illustrated).

Sensitivity to organic solvents and RNAase. The phage suspension was completely inactivated by chloroform and underwent a $70 \%$ reduction in titre as a result of diethyl ether treatment. Control phage $\mathrm{C}-1$ was completely resistant to these two treatments while phages $\mathrm{X}, \mathrm{IKe}, \mathrm{C}-2$, PR64FS and fd were completely inactivated by chloroform though fully resistant to diethyl ether. The plating titre of phages $\mathrm{tf}-1$ and $\mathrm{C}-2$ on their respective hosts was unaffected by the presence of $40 \mu \mathrm{g} \mathrm{RNAase} \mathrm{ml}^{-1}$ in media while that of phage C-1 was reduced to zero.

Phage serology. The two phage tf-1 antisera had homologous $K$ values of 84 and $112 \mathrm{~min}^{-1}$. These antisera had no neutralizing effect $(K=0)$ on phages X, IKe, C-2, PR64FS and fd.

Host range. Phage tf -1 formed plaques only on strains of E. coli, S. typhimurium and $K$. oxytoca carrying plasmid pIN25 at $30^{\circ} \mathrm{C}$ and not at 37 or $42^{\circ} \mathrm{C}$ (see above, Table 1). It did not plate or propagate on any of the other bacterial species carrying this plasmid (Table 1 ). The phage was very selective as it did not plate or propagate on any of the above bacterial strains carrying other IncT plasmids (Table 1 and not shown). Some clearing of the culture did occur in areas of the host lawn (incubated at $30^{\circ} \mathrm{C}$ ) where high concentrations of the phage had been dropped. This clearing was found with the above strains carrying any of the other IncT plasmids tested and was 

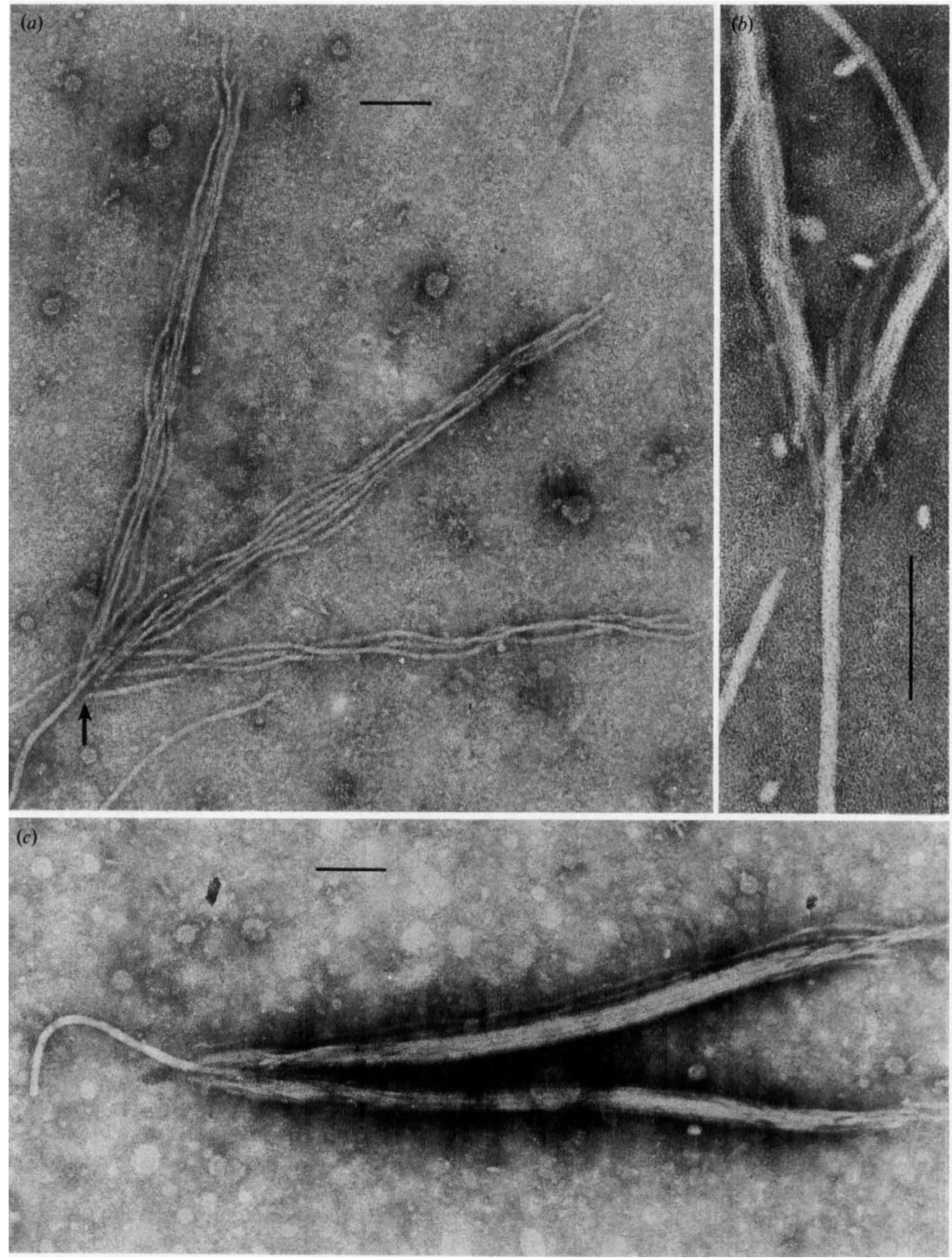

Fig. 1. Adsorption sites of phage tf-1. E. coli JE2571-2 harbouring the appropriate plasmid was grown overnight at $30^{\circ} \mathrm{C}$. Phage adsorption was for $2 \mathrm{~h}$ at $30^{\circ} \mathrm{C}$. Bars, $100 \mathrm{~nm}$. (a) Three loose bundles of virions attached near the distal tip of a pIN25 pilus (arrow). (b) Location of adsorption sites on plasmid R402 pilus. (c) Two dense bundles of phage tf-1 virions adsorbed near the tip of a pilus determined by plasmid Rtsl. 
Table 1. Host range of phage $t$ - 1 on bacterial strains harbouring IncT plasmids

Drops of dilutions of a phage suspension (titre $5 \times 10^{11}$ p.f.u. $\mathrm{ml}^{-1}$ ) were spotted on lawns of organisms contained in top-layer agar. Phage propagation was done as described in Methods. Unless otherwise indicated, experiments were done at $30^{\circ} \mathrm{C}$.

\begin{tabular}{|c|c|c|c|}
\hline \multirow[b]{2}{*}{ Host } & \multicolumn{2}{|c|}{ Phage action } & \multirow{2}{*}{$\begin{array}{l}\text { Plasmid } \\
\text { reference }\end{array}$} \\
\hline & Plaque formation* & Propagation $\dagger$ & \\
\hline E. coli JE2571-1(Rts1) & $(+)$ & - & $1,2,4$ \\
\hline E. coli $\operatorname{CSH} 2(\mathrm{Rts} 1)$ & $(+)$ & - & $1,2,4$ \\
\hline S. typhimurium M827-2(Rts1) & $(+)$ & - & $1,2,4$ \\
\hline E. coli JE2571-2(pIN25) & + & + & 3,4 \\
\hline E. coli JE2571-2(pIN25)§ & $(-)$ & - & 3,4 \\
\hline S. typhimurium M827-2(pIN25) & + & ND & 3,4 \\
\hline S. typhimurium M827-2(pIN25)§ & $(-)$ & - & 3,4 \\
\hline P. mirabilis PM5006(pIN25) & $(-)$ & - & 3,4 \\
\hline P. morganii $2815-2(\mathrm{pIN} 25)$ & $(-)$ & - & 3,4 \\
\hline P. rettgeri $\mathrm{NCTC} 8893(\mathrm{pIN} 25)$ & $(-)$ & - & 3,4 \\
\hline P. rettgeri $\mathrm{R} 49(\mathrm{pIN} 25)$ & $(-)$ & - & 3,4 \\
\hline Pr. alcalifaciens $\mathrm{P} 29-2(\mathrm{pIN} 25)$ & $(-)$ & - & 3,4 \\
\hline K. pneumoniae G162(pIN25) & $(-)$ & - & 3,4 \\
\hline K. oxytoca G147(pIN25) & + & ND & 3,4 \\
\hline K. oxytoca G147(pIN25)§ & $(-)$ & - & 3,4 \\
\hline Sr. marcescens $\mathrm{Sr} 41-2(\mathrm{pIN} 25)$ & $(-)$ & - & 3,4 \\
\hline E. coli JE2571-1(R394) & $(+)$ & - & $1,2,4$ \\
\hline K. oxytoca G147(R394) & $(+)$ & - & $1,2,4$ \\
\hline E. coli $\mathrm{JE} 2571(\mathrm{R} 401)$ & $(+)$ & - & 4,5 \\
\hline K. oxytoca G147(R401) & $(+)$ & - & 4,5 \\
\hline P. rettgeri $\mathrm{R} 49(\mathrm{R} 401)$ & $(-)$ & - & 4,5 \\
\hline E. coli JE2571(R402) & $(+)$ & - & 4,5 \\
\hline K. oxytoca G147(R402) & $(+)$ & - & 4,5 \\
\hline P. rettgeri NCTC $8893(\mathrm{R} 402)$ & $(-)$ & - & 4,5 \\
\hline E. coli JE2571-2(R414b) & $(+)$ & - & 1,6 \\
\hline S. typhimurium M827-2(R414b) & $(+)$ & - & 1,6 \\
\hline
\end{tabular}

- + , Efficiency of plating, 1; (+), clearing but discrete plaques not observed; $(-)$, no plaques or clearing observed.

++ , At least a 10-fold titre increase above that of the negative control obtained on three separate occasions; - , no increase in phage titre above that of the negative control on two separate occasions; ND, not done.

$\ddagger 1$, Jacob et al. (1977); 2, Bradley (1980); 3, Levy et al. (1985); 4, Bradley et al. (1981b); 5, Coetzee et al. (1972); 6, Matthew \& Hedges (1976).

$\S$ Experiments done at 37 and $42^{\circ} \mathrm{C}$.

specific in that similar areas of clearing were not found on lawns of isogenic strains lacking IncT plasmids. Failure to plate on these strains occurred despite the fact that all plasmid-carrying hosts (apart from Rtsl) produced sex pili constitutively as judged by plate plasmid transfer frequencies of $>1 \times 10^{-1}$ transconjugants per donor per $\mathrm{h}$ and plated phage $\mathrm{t}$ (Table 1 and not shown; see Bradley et al., 1981 b). Plasmid Rts 1 transferred at 100-fold lower frequencies and could have formed too few conjugative pili to support plaque formation by the phage (not shown; Bradley et al., $1981 b$; Bradley \& Whelan, 1985, but see Bradley, $1980 a$ ). Plating a total of $2 \times 10^{12}$ p.f.u. on any of the other IncT plasmid-carrying strains at $30^{\circ} \mathrm{C}$ did not yield plaques.

The phage did not plate on any of the strains carrying plasmids belonging to the other incompatibility groups tested (see Methods) nor did it plate on isogenic strains lacking plasmids.

\section{DISCUSSION}

The method of isolation of the phage (see Methods) did not necessarily impose temperaturerestrictive properties on it. Phages have been isolated at $26^{\circ} \mathrm{C}$ which were not temperature sensitive (Coetzee et al., 1986). Phage tf-1 adsorbs to short pIN25 pili at $37^{\circ} \mathrm{C}$ but the temperature-sensitivity of plaque formation by phage tf-1 still does not prove which component, phage or plasmid, is responsible (see Introduction and Results). 
The ether-sensitivity of the phage is exceptional (see Results). Only one other ether sensitive filamentous phage, phage Pf-1, has been described. Lipid was not detected in the structure of that phage (Amako \& Yasunaka, 1977). The microscopic morphology of phage tf-1 resembled that of other filamentous phages and did not reveal structures possibly indicative of lipid (see Results and Coetzee et al., 1979, Figs 1-3).

The low homologous $K$ values of phage tf-1 antisera are reminiscent of the values of sera against lipid-containing phages (Coetzee et al., 1979). However, phage $\mathrm{Pf}-1$, the one other ethersensitive filamentous phage described (see above) elicited an antiserum with a $K$ value of $580 \mathrm{~min}^{-1}$ (Minamishima et al., 1968). Other filamentous phages (Meynell \& Lawn, 1968; Coetzee et al., 1980, 1986) also raised antisera with homologous $K$ values $>500 \mathrm{~min}^{-1}$ although $K$ values of $<100 \mathrm{~min}^{-1}$ have been reported for sera against phage fd (Hohn et al., 1971), phage HR (Hsu, 1968) and phage Xf (Kuo et al., 1967).

The only other shaft-adsorbing filamentous phage that has been reported is C-2 (Bradley et al., 1982). It differs from tf- 1 by adsorbing along the entire length of the shaft rather than just to a short section near the tapered tip. Adsorption of the RNA phage $t$ is also restricted to the latter location (Bradley et al., 1981 b). Whenever investigated (Bradley, 1977, 1980a, 1984; Bradley et al., 1981 a, c, 1983; Coetzee et al., 1985b) the tapered end of a pilus was found to be the distal termination and it is thus assumed that phage tf-1 adsorption (Fig. 1) occurs to the distal of the two ends of the pilus. Since $T$ pili are presumably formed from a single protein (pilin), the observed phage adsorption sites are possibly produced by pilin subunits in a different orientation from those in the main body of the pilus. The change in orientation would occur where the pilus starts to taper from a cylinder to a point (Fig. $1 b$ ). Alternatively, the tapered section of the pilus may contain a minor species of subunit absent from the remainder of the filament. Tip-adsorbing filamentous phages usually attach to pili determined by plasmids of more than one Inc group (Bradley et al., 1981 $a$, 1983) but the shaft-adsorbing filamentous phages $\mathrm{C}-2$ and $\mathrm{tf}-1$ are specific for a single pilus type. In this respect the latter phages resemble RNA-containing phages (Coetzee et al., 1979).

Phage tf-1 did not plate on pIN25 plasmid-carrying species of the family Enterobacteriaceae other than $E$. coli, $S$. typhimurium, and $K$. oxytoca despite constitutive conjugative pilus production (see Results). Analogous situations with other phages and plasmids have repeatedly been encountered (Bradley et al., 1981 a, b; Coetzee et al., 1979, 1985b) and an explanation may be that while still providing adequate phage receptors, different species may not be able to support phage multiplication. Also, in some cases, pili may be modified in a particular bacterial plasmid host to prevent adsorption (Hua et al., 1981). Nevertheless the fact that the Proteus and Providencia pIN25-harbouring strains were not lysed by the phage is surprising considering the derivation of these plasmids (see Introduction).

The finding that phage tf-1 adsorbs to pili of T plasmids other than pIN25 while not forming plaques on lawns of the corresponding bacterial hosts (see Results) is difficult to interpret. Plasmid pIN25 pili are unlikely to be more efficient carriers of the phage than pili of other IncT plasmids as they transmit phage t equally well (Bradley et al., 1981 b). It seems unlikely that pIN25 uniquely carries a gene for a function required by tf- 1 as there is no evidence that plasmids help plasmid-specific phages in any way other than providing receptor sites. It may be more natural to think in terms of most $T$ plasmids having a mechanism which blocks the multiplication of phage tf- 1 .

In this respect the IncT plasmid Rtsl codes for a thermosensitive endonuclease which specifically cleaves phage T4 DNA. This has the effect of restricting growth of the phage, in appropriate plasmid-bearing strains, at $37^{\circ} \mathrm{C}$ but not at $42^{\circ} \mathrm{C}$ (Ishaq \& Kaji, 1980). Phage tf-1 certainly did not form plaques on any plasmid-bearing strain at 37 or $42^{\circ} \mathrm{C}$ but this does not prove the absence of an enzyme, analogous to the Rts 1 endonuclease produced by plasmids other than pIN25, as the phage itself could be thermosensitive (see above).

In the absence of a better solution, an explanation for the specific areas of partial clearing produced by the phage on lawns of suitable strains carrying IncT plasmids other than pIN25 (see Results) could be that only strains with the latter plasmid provide fully functional intracellular phage assembly systems while the other plasmids do not function very efficiently in this respect. 
This could reduce growth of the host after initial infection and any free phage progeny would rapidly be depleted due to efficient adsorption (see Results) to an ever-increasing supply of pili (see Coetzee et al., 1986).

We thank Jeanette Whelan, Bertha Hounsell, Sarel van Biljon and Elma Cloete for excellent technical assistance. D.E.B. is in receipt of a grant (no. MT5608) from the Medical Research Council of Canada.

\section{REFERENCES}

Ackermann, H.-W., Audurier, A., Berthiaume, L., JoNes, L. A., MAYo, J. A. \& VidAVER, A. K. (1978). Guidelines for bacteriophage characterization. $A d$ vances in Virus Research 23, 1-24.

ADAMS, M. H. (1950). Methods of study of bacterial viruses. Methods in Medical Research 2, 1-73.

Amako, K. \& YasunakA, K. (1977). Ether induced morphological alteration of $\mathrm{Pf}-1$ filamentous phage. Nature, London 267, 862-863.

Beumer, J., Hannecart-Pokorni, E. \& Godard, C. (1984). Bacteriophage receptors. Bulletin de l'Institut Pasteur 82, 173-253.

BRADLEY, D. E. (1977). Characterization of pili determined by drug resistance plasmids $R 711 \mathrm{~b}$ and R778b. Journal of General Microbiology 102, 349363.

BRADLEY, D. E. $(1980 a)$. Morphological and serological relationships of conjugative pili. Plasmid 4, 155169.

BradLEY, D. E. (1980b). Determination of pili by conjugative bacterial drug resistance plasmids of incompatibility groups $\mathbf{B}, \mathbf{C}, \mathrm{H}, \mathrm{J}, \mathrm{K}, \mathrm{M}, \mathrm{V}$ and $\mathrm{X}$. Journal of Bacteriology 141, 828-837.

BRADLEY, D. E. (1984). Characteristics and function of thick and thin conjugative pili determined by transfer-derepressed plasmids of incompatibility groups $\mathrm{I}_{1}, \mathrm{I}_{2}, \mathrm{I}_{5}, \mathrm{~B}, \mathrm{~K}$ and $\mathrm{Z}$. Journal of General Microbiology 130, 1489-1502.

BRADLEY, D. E. (1985). Transfer systems of K88 and K99 plasmids. Plasmid 13, 118-128.

Bradley, D. E. \& WhelaN, J. (1985). Conjugation systems of IncT plasmids. Journal of General Microbiology 131, 2665-2671.

Bradley, D. E., Taylor, D. E. \& Cohen, D. R. (1980). Specification of surface mating systems among conjugative drug resistance plasmids in Escherichia coli K-12. Journal of Bacteriology 143, 1466-1470.

Bradley, D. E., Coetzee, J. N., Bothma, T. \& HedGes, R. W. (1981a). Phage X: a plasmiddependent, broad host range, filamentous bacterial virus. Journal of General Microbiology 126, 389-396.

Bradley, D. E., Coetzee, J. N., Bothma, T. \& HEDGES, R. W. (1981b). Phage t: a group T plasmiddependent bacteriophage. Journal of General Micro-
Bradley, D. E., Coetzee, J. N. \& Hedges, R. W. (1983). IncI ${ }_{2}$ plasmids specify sensitivity to filamentous bacteriophage IKe. Journal of Bacteriology 154, 505-507.

COETZEE, J. N. (1972). Genetics of the proteus group. Annual Review of Microbiology 26, 23-54.

CoetzeE, J. N. (1983). Lysogeny in Proteus rettgeri and the host-range of $P$. rettgeri and $P$. hauseri bacteriophages. Journal of General Microbiology 131, 219229.

Coetzee, J. N., Datta, N. \& Hedges, R. W. (1972). R factors from Proteus rettgeri. Journal of General Microbiology 72, 543-552.

Coetzee, J. N., Lecatsas, G., Coetzee, W. F. \& HEDGes, R. W. (1979). Properties of R plasmid R772 and the corresponding pilus-specific phage PR772. Journal of General Microbiology 110, 263-273.

Coetzee, J. N., Sirgel, F. A. \& Lecatsas, G. (1980). Properties of a filamentous phage which adsorbs to pili coded by plasmids of the IncI complex. Journal of General Microbiology 117, 547-551.

Coetzee, J. N., Bradley, D. E. \& Hedges, R. W. (1982). Phages $\mathrm{I} \alpha$ and $\mathrm{I}_{2}-2$ : Incl plasmid-dependent bacteriophages. Journal of General Microbiology 128, 2797-2804.

Coetzee, J. N., Bradley, D. E., Hedges, R. W., Fleming, J. \& LeCaTsas, G. (1983). Bacteriophage $\mathbf{M}$ : an incompatibility group $\mathbf{M}$ plasmid-specific phage. Journal of General Microbiology 129, 22712276.

Coetzee, J. N., Bradley, D. E., Fleming, J., du TOIT, L., Hughes, V. M. \& HeDGes, R. W. (1985a). Phage pilH $\alpha$ : a phage which adsorbs to IncHI and IncHII plasmid-coded pili. Journal of General Microbiology 131, 1115-1121.

Coetzee, J. N., Bradley, D. E., lecatsas, G., du Tort, L. \& HEDGES, R. W. (1985b). Bacteriophage D: an IncD group plasmid-specific phage. Journal of General Microbiology 131, 3375-3383.

Coetzee, J. N., Bradley, D. E., Hedges, R. W., HUGHes, V. M., MCCONNELL, M., DU TOIT, L. \& TWEEHUYSEN, M. (1986). Bacteriophages $\mathrm{F}_{0}$ lac $h$, SR, SF: phages which adsorb to pili encoded by plasmids of the new S-complex. Journal of General Microbiology 132, 2907-2917. 
Hohn, B., von Schütz, H. \& MaRvin, D. A. (1971). Filamentous bacterial viruses. II. Killing of bacteria by abortive infection with fd. Journal of Molecular Biology 56, 155-165.

HuA, T.-C., Scholl, D. R. \& Jollick, J. D. (1981). Functional modification of the plasmid RP1-specified pilus by Caulobacter vibrioides. Journal of General Microbiology 124, 119-128.

IsHAQ, M. \& KAJI, A. (1980). Mechanism of T 4 phage restriction by plasmid RTS 1. Journal of Biological Chemistry 255, 4040-4047.

Jacob, A. E., Shapiro, J. A., Yamamoto, L., Smith, D. I., Cohen, S. N. \& BeRG, D. (1977). Plasmids studied in Escherichia coli and other enteric bacteria. In DNA Insertion Elements, Plasmids and Episomes, pp. 607-638. Edited by A. I. Bukhari, J. A. Shapiro \& S. L. Adhya. Cold Spring Harbor, New York: Cold Spring Harbor Laboratory.

KHATOON, H., IYER, R. V. \& IYER, V. N. (1972). A new filamentous bacteriophage with sex-factor specificity. Virology 48, 145-155.

Kuo, T. T., Huang, T.-C., Wu, R.-Y. \& Yang, W.-M. (1967). Characterization of three bacteriophages of Xanthomonas oryzae (Uyeda et Ishiyame) Dowson. Botanical Bulletin of Academia sinica 8, 246-254.

Levy, S. B., Hedges, R. W., Sullivan, F., Medeiros, A. A. \& Sosrosputro, H. (1985). Multiple antibiotic resistance plasmids in Enterobacteriaceae isolated from diarrhoeal specimens of hospitalized children in Indonesia. Journal of Antimicrobial Chemotherapy 16, 7-16.

Marvin, D. A. \& Hoffmann-Berling, H. (1963). Physical and chemical properties of two new small bacteriophages. Nature, London 197, 517-518.

MAR VIN, D. A. \& HoHN, B. (1969). Filamentous bacterial viruses. Bacteriological Reviews 33, 172209.

Matsumoto, H., Tazaki, T. \& Hosogaya, S. (1973). A generalized transducing phage of Serratia marcescens. Japanese Journal of Microbiology 17, 473479.

Matthew, M. \& Hedges, R. W. (1976). Analytical isoelectric focussing of $\mathbf{R}$-factor determined $\beta$ lactamases: correlation with plasmid compatibility. Journal of Bacteriology 125, 713-718.
MEynell, G. G. \& LAWN, A. M. (1968). Filamentous phages specific of the I sex factor. Nature, London 217, 1184-1186.

Minamishima, Y., Takeya, K., OHnishi, Y. \& Amako, K. (1968). Physicochemical and biological properties of fibrous Pseudomonas bacteriophages. Journal of Virology 2, 208-213.

OdakuRa, Y., Hashimoto, H. \& Mitsuhashi, S. (1977). Temperature sensitive $\mathbf{R}$ plasmids isolated from Proteus strains. Microbiology and Immunology 21, 621-629.

Salivar, W. O., Tzagoloff, H. \& Pratt, D. (1964). Some physical-chemical and biological properties of the rod-shaped coliphage M13. Virology 24, 359-371.

SCHWARTZ, M. (1980). Interaction of phages with their receptor proteins. In Bacterial Viruses, Receptors and Recognition, series B, vol. 6, Virus Receptors, part 1, pp. 61-94. Edited by L. Randall \& L. Philipson. London: Chapman \& Hall.

Sirgel, F. A., Coetzee, J. N., Hedges, R. W. \& Lecatsas, G. (1981). Phage C-1: an IncC group plasmid-specific phage. Journal of General Microbiology 122, 155-160.

SPRATt, B. G., Rowbury, R. H. \& MEYNell, G. G. (1973). The plasmid of Salmonella typhimurium LT2. Molecular and General Genetics 121, 347-353.

TERAWAKI, Y. \& Rownd, R. (1972). Replication of the $\mathbf{R}$ factor Rtsl in Proteus mirabilis. Journal of Bacteriology 109, 492-498.

Terawaki, Y., Takayasu, H. \& Akiba, T. (1967). Thermosensitive replication of a kanamycin resistance factor. Journal of Bacteriology 94, 687-690.

To, C. M., To, A. \& Brinton, C. C. (1975). A new epiviral pilus, the $\mathrm{E}$ pilus, and a new RNA pilus phage pilE/R1. Abstracts of the Annual Meeting of the American Society for Microbiology, p. 259, abstract S276.

Watanabe, M. \& August, J. T. (1967). Methods for selecting RNA bacteriophage. Methods in Virology 3, 337-350.

Yokota, T., Kanamaru, Y., Mori, R. \& Akiba, T. (1969). Recombination between a thermosensitive kanamycin resistance factor and a non-thermosensitive multiple drug resistance factor. Journal of Bacteriology 98, 863-873. 